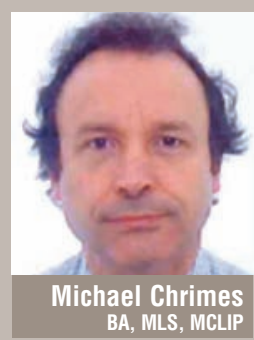

is head of knowledge transfer at the Institution of Civil Engineers, UK

\title{
St Katharine Docks, London-Telford's high-speed harbour
}

\author{
The current paper describes Thomas Telford's work as engineer \\ for St Katharine Docks, London, in the context of his role as \\ a maritime engineer. Although not the largest in London, they \\ presented one of the most challenging projects in Telford's career, \\ not least owing to the extreme time pressure he was put under \\ to get the docks trading in London's then busy and profitable \\ shipping industry. With up to 1000 construction workers on \\ site, and despite a major flood, the first ship entered the dock in \\ 1828 - just three years after contracts were let.
}

In engineering terms Telford is generally remembered as a builder of roads and bridges. ${ }^{1-3}$ This is understandable given the mileage of roads he surveyed and the iconic bridges he designed. He was, however, active in all branches of the profession, not least in docks and harbours.

His first position of real responsibility, as clerk of works on the commissioner's house at Portsmouth Dockyard, provided him with the opportunity to observe work there. His involvement with the British Fisheries Society followed soon after: $\mathrm{Gibb}^{1}$ suggests a date of around 1789. This resulted in his surveying the coast of Scotland for suitable harbour sites, ${ }^{4}$ and an early opportunity to demonstrate his interest in the innovative use of materials when he advised on the suitability of various cements for harbour works, specifically at Stein in Skye. He reported on the pozzolanic qualities of Parker's cementone of the first 'artificial' or 'Roman' cements to come on the market as a rival to natural pozzolan or trass. ${ }^{5}$

The Fisheries Society work led directly to Telford's reports on the improvement of communications in the Highlands more generally as a means of economic revitalisation. ${ }^{6} \mathrm{He}$ strongly advocated the development of Wick and Peterhead as well as the Caledonian Canal. Generally, however, the consequent harbour works were mostly modest landing piers.

Certainly his early practical experience does not stand comparison with that of his mentor
William Jessop ${ }^{7,8,}$ engineer for Dublin, Bristol and West India Docks, or his great rival John Rennie, ${ }^{9}$ engineer for London Docks, and the great naval dockyard improvements of the Napoleonic period. This said, Telford's work with Jessop on the Caledonian Canal involved the design of the great sea-locks at Corpach and Clachnacarry. The latter involved an early example of ground stabilisation by preloading. ${ }^{10}$

\section{Previous harbour experience}

Work around the coast of Scotland would have also provided Telford with plenty of opportunity to observe the combined forces of tide, wave and wind. By the mid-1820s when he was appointed engineer to St Katharine Docks, Telford had also designed major harbour schemes at Dundee and Aberdeen. It should be noted that Telford's reports are collated in Reports upon the Harbour of Aberdeen, ${ }^{11}$ and some details can also be found in The Story of Telford. ${ }^{1}$ Although his plans for Aberdeen were not fully implemented until after his death, Dundee ${ }^{12}$ was an outstanding piece of work.

Robert Southey noted when he visited Dundee in the autumn of $1819^{13}$

'Before breakfast I went with Mr Telford to the harbour, to look at his works, which are of great magnitude and importance, a huge floating dock and the finest graving dock I ever saw.' 
When Telford advised on the harbour facilities in 1814, no real improvements had been made since John Smeaton had reported in 1769. The local authorities were widely criticised for their apathy, and a special harbour commission was set up to manage improvements, with Telford as engineer. A new graving dock was opened in 1823 and the King William Fourth Dock opened in November 1825.

In 1820 Telford was consulted about steam ferry services across the Tay at Dundee and designed the ferry piers there. Dock facilities were improved again at Dundee in 1831-1834, when Telford recommended converting the west harbour to a dock. This was opened in 1834 as Earl Grey Dock. He modelled the dock gates on John Rennie's designs at Sheerness. James Leslie, who became a leading Scottish civil engineer in the Victorian period, was resident engineer for the later work. More than $£ 150000$ was spent in harbour improvements at Dundee, which was one of Telford's major schemes in Scotland.

Telford had also reported on work at Folkestone (he introduced columnar piers here in $1808^{14}$ ), King's Lynn, Bude (work was carried out around 1823-1827 with James Green $\left(\right.$ BDCE1) ${ }^{7}$ ) and Glasgow, ${ }^{15}$ and succeeded Rennie at Fraserburgh (1808), Holyhead, Howth and Dublin (1821). By 1824 he was well experienced both as a manager of large projects and with maritime works.

\section{Development of London's docks}

The construction of St Katharine Docks (1826-1830) marks the end of the first great phase of dock construction in the Port of London. It had begun in February 1800 with the excavations for West India Docks, and by 1833 had resulted in the provision of 250 acres (100 ha) of enclosed water in the Port of London. ${ }^{16-20}$ In terms of water acreage, St Katharine Docks was a relatively modest scheme, but in terms of engineering challenges the construction is of considerable interest. It was also the largest dock scheme designed by Thomas Telford.

The ports of Liverpool and Hull had already developed modest dock systems in the eighteenth century. ${ }^{21,22}$ Construction of London's docks followed an explosion in civil engineering activity in the 1790s, the period of canal mania, which created an unprecedented demand for civil engineers and saw the emergence of a new generation of civil engineers under the leadership of John Smeaton and contemporaries such as James Brindley. ${ }^{23}$ Smeaton's pupils William Jessop, John Rennie and latterly Thomas Telford all became involved in developing London's docks.

The proposals for dock construction in London advocated in the 1790s were on a largely unprecedented scale in the history of civil engineering in the British Isles, but they could draw on a wealth of practical experience built up over the previous decades. The demand for docks in London was driven by similar factors to those that had been driving the expansion of civil engineering over the previous 40 years, although there were factors peculiar to the Port of London. The growth of trade handled in the port after 1750 had resulted in severe overcrowding in the river, where much of the shipping had to wait while its cargo was unloaded into lighters for ferrying the various quays legally designated to handle cargoes attracting customs duty. In the 1790s as many as 880 ships might be moored in the river, discharging and loading cargoes.

Delays in cargo handling were compounded by pilfering, and a concerted campaign by merchants resulted in the parliamentary approval of three major docks schemes at the start of the nineteenth century - the West India, London and East India Docks. These offered the prospect of not only expanding the quays available for berthing ships, but also provided secure accommodation for ships and warehousing of goods as a safeguard against pilfering. The successful construction of these projects, costing millions of pounds, in the period 1800-1806 was a great testimony to the capabilities of the civil engineering industry of the time.

The immediate financial success of the projects-West India Docks' annual profits exceeded $£ 100000$ from its opening in 1803 to 1822 - and continuing growth in trade encouraged further development of dock facilities in the Port of London over the following decade, with the design and construction methods employed serving as a model for successive schemes.

\section{Proposals for St Katharine Docks}

Despite the ongoing improvements, in the 1820s there was still a demand for further development. Some merchants were dissatisfied with the charges levied by the main companies which all operated under some form of privilege; others were probably so encouraged by the profitability of the early schemes that they wanted to invest in their own company. The leading protagonist in articulating these demands was John Hall.

With the end of the West India Docks' monopoly in 1823 , the situation was reviewed by a parliamentary committee on trade, ${ }^{24}$ which recommended an end to privileges. The passage of the Warehousing Act in 1823 served as the necessary catalyst and in 1824 Hall was the chief proponent of the St Katharine Docks Bill.

St Katharine's, in the shadow of the Tower of London and close to the City of London, had been identified as a potential dock site in the 1790s by William Vaughan, but no action had been taken-perhaps because its potential dock acreage was so small—although a small creek dock already existed adjoining St Katharine's Hospital.

The presence of the Norman foundation church in particular aroused concern about the impact of demolition of the area, but a satisfactory settlement with the trustees paved the way for the promoters' success in obtaining an Act in 1825 . The cost of this, and compensation to a brewery and the landlords of 1100 mostly unsanitary dwellings, made the site among the most costly acquisitions involved in contemporary dock construction. Opposition was most vocal from the London Docks, which were the closest neighbours and competitors, immediately to the east.

Hall and his supporters argued that the charges of the existing dock companies were too high and anyway, as their monopolies ran out, many traders would prefer docks closer to London. He also argued that cargo steamships were growing in number, while existing facilities were already fully stretched.

In fact, on completion of the new docks, there was insufficient business for all the facilities in the Port of London. St Katharine's competitive rates forced dividends generally down, and St Katharine Docks itself only paid a dividend of $23 / 4-3 \%$ in its first five years-well below expectations. In the longer term, the opening of St Katharine Docks led to the progressive merging of the London dock companies to deal with destructive competition.

\section{Initial plans}

It can be assumed that Telford and Philip Hardwick were first approached in 1823 about the proposal as the first prospectus dated 24 February 1824 contains their estimate for construction dated 18 February, see Table 1. This was the proposal that went to parliament that month.

The 1824 plans show how Telford and Hardwick were thinking of maximising the warehouse accommodation on the site, and differ in detail only from the final plans, with two entrance locks in parallel and inner lock chambers between the entrance basin and the main dock. It was costed at $£ 1.35$ million (Figs 1 and 2). ${ }^{25}$

Following passage of the Act on 10 June 1825 , the St Katharine Dock Company was constituted with Hall as secretary and Thomas Took as chairman. With the successive ending of the other companies' monopolies, time was of the essence,

\begin{tabular}{lr}
$\begin{array}{l}\text { Table 1. Telford and Hardwick's initial estimate } \\
\text { for construction, } 18 \text { February 1824 }\end{array}$ \\
\begin{tabular}{lr} 
Purchase of property & $£ 278000$ \\
Dock excavation & $£ 270446$ \\
Warehouse construction & $£ 372000$ \\
Surveys, etc. & $£ 50000$ \\
Total & $£ 970446$ \\
\hline
\end{tabular} \\
\hline
\end{tabular}




\section{'As a practical engineer, responsible for the success of difficult operations, I must be allowed to protest against such haste'}

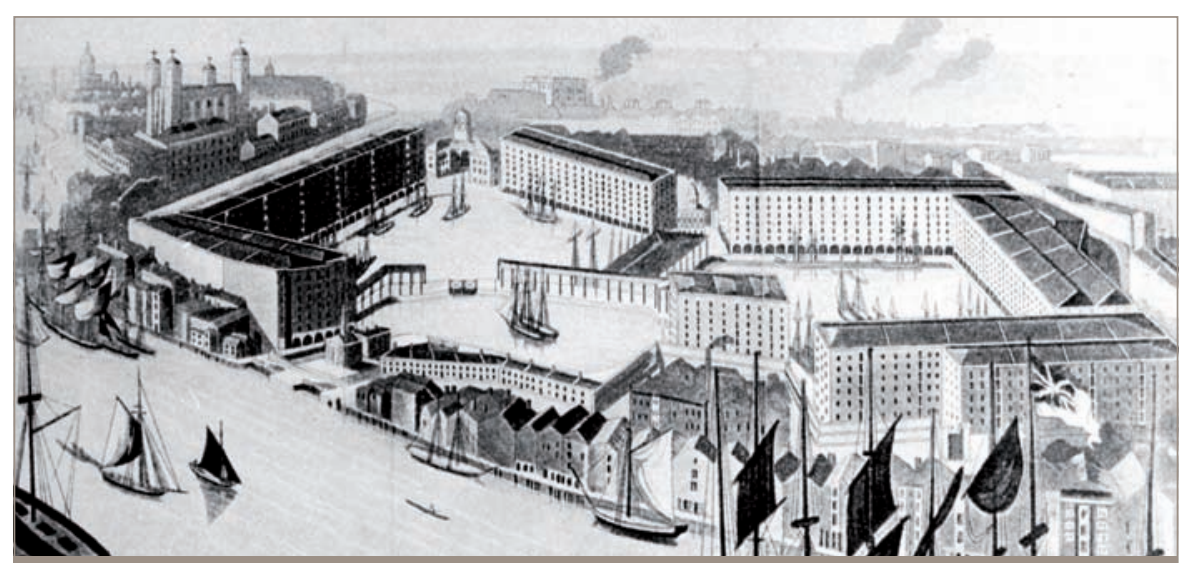
Fig. 1. Early artist's impression of the proposed St Katharine Docks and warehouses just east of the Tower of London

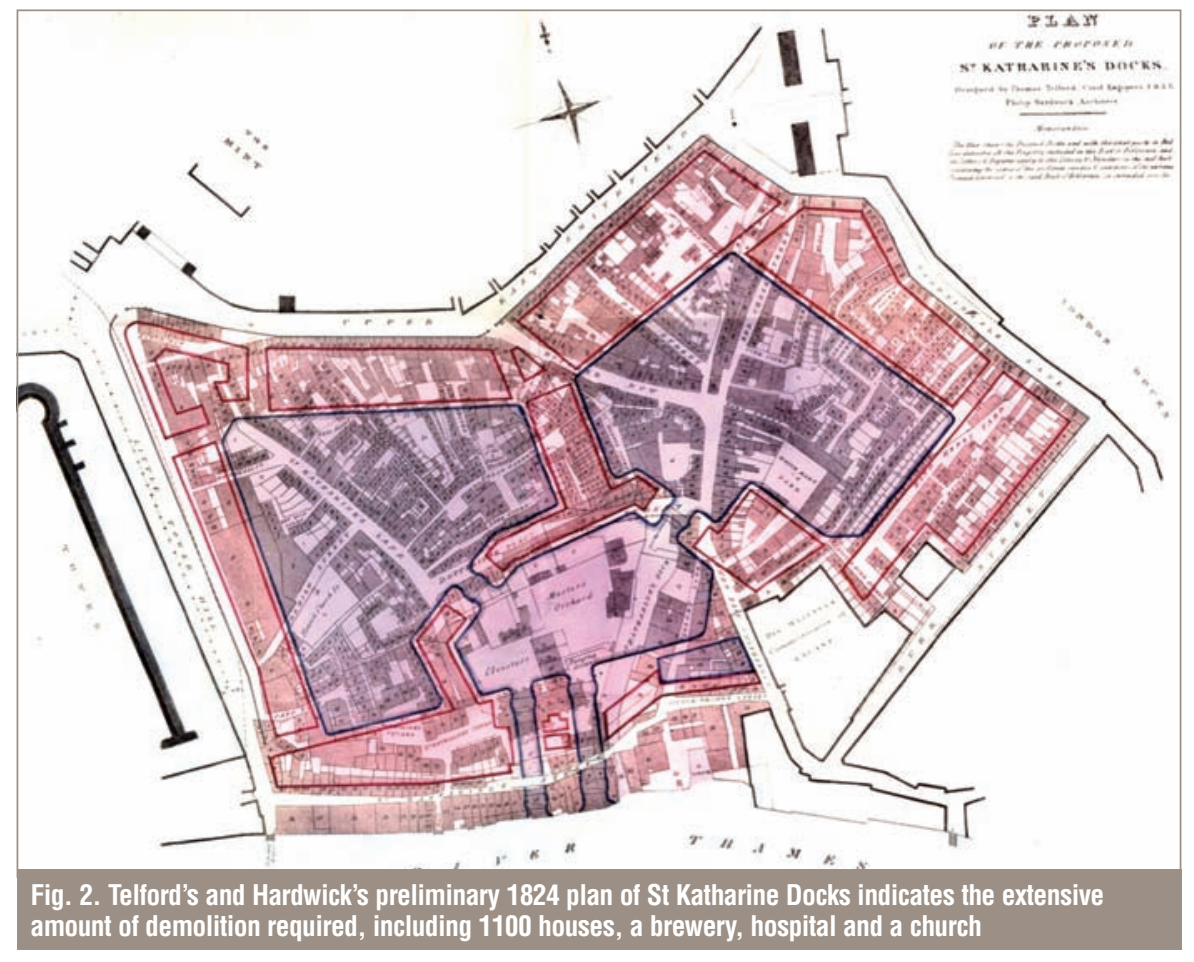

projects all over Britain, he had the reputation of success to inspire the choice.

While Telford was appointed engineer, Hardwick ${ }^{27}$ was appointed architect and surveyor. This followed the pattern of West India Docks and London Docks, where George Gwilt and Daniel Alexander, respectively, fulfilled similar functions alongside the dock engineers.

The prospectus issued in $1824^{28}$ proclaimed

'It is computed that the St Katharine Docks and Basin, will with great convenience afford accommodation, annually, for about 1400 Merchant Ships ... Increased facilities will be afforded to the ingress and egress of shipping by the improved application of mechanical powers, by means of which ships and lighters, at a very trifling expense to the Company, may, in the night as well as by day, be locked in and out of the Docks during any period of tide; as the sills of the outward gates will be so constructed as to provide for ten feet depth at low water, and from twenty-six to thirty feet at the height of spring tides...According to the estimates proved before Committees of Parliament, the total cost ... will be about $£ 1,350,000$, - whilst the Capital Stock of the London Dock Company amounts to upwards of $£ 3,200,000$.'

\section{Developing the design}

Telford described the design process thus ${ }^{29}$

When the space necessary for warehouses and entrances was subtracted 10 acres only remained for the actual docks - it being obvious that the accommodation required could not be obtained by the simpler forms of squares and parallelograms. I was, from necessity, led to adopt the shape of the docks to that of the ground; and this was so managed, after alternative consideration, as to become really advantageous, as affording an increased extent of wharfage and two docks instead of one, by which distribution of trade was likely to be better arranged; with a further advantage, that in case it should at any time be found necessary to empty one dock, the water may be returned at full height in the other.'

It is not known for certain who helped Telford with the preliminary plan and estimates. At that time, 1823, Henry Robinson Palmer was his chief assistant while two pupils, Joseph Mitchell ${ }^{30}$ - who gives a vivid picture of work with Telford-and Alexander Gibb ${ }^{31}$ assisted in the office in Abingdon Street in Westminster. It is probable that, after Telford and Hardwick's formal appointment on 16 June 1825 as engineer and architect following the passage of the Act on 10 June 1825, Telford worked up the detail of the scheme with Hardwick and the soon-to-be- 
appointed resident engineer Peter Logan.

Telford was then paid £291 for work already carried out. His salary was at $£ 500$ a year, the same as that of Logan and Hardwick. Hardwick's assistant Douthwaite was paid only $£ 300$, suggesting that the company recognised the amount of responsibility and time required of the resident engineer compared with Telford. Logan was experienced in harbour work under Telford at Dundee.

On 11 October 1825 Telford and Logan presented the plans, specifications and revised estimates, see Table 2 and Fig. 3.

Mitchell and Gibb had returned to Scotland and therefore the drawings were prepared by William Daniel Anderson, ${ }^{7}$ who was now Telford's pupil and, as can be seen from extant drawings, was evidently a gifted draughtsman. Telford's experience of port works was largely confined to Scottish harbours, many of a modest scale, but he had other models to draw on, notably the sea-locks on the Caledonian Canal on which he had worked with William Jessop, similar works on the Gota Canal and the large collection of drawings of the West India Docks and East India Docks that he possessed, some of which are extant in the Museum of London in Docklands. These, combined with Logan's experience, resulted in preparation of a well-thoughtout scheme, as exemplified by the cofferdams.

Telford's knowledge of such works can be seen in the article he wrote for the Edinburgh Encyclopaedia where he illustrated the dams designed by the contractor John Simpson on the Caledonian Canal and elsewhere. ${ }^{32}$ Although detailed evidence of the design process is lacking, parallels can be drawn with evidence from his 1833 diary, which is in the National Library of Scotland, and the only one known to survive. At that time Telford was consulted about proposals for Sydney Harbour, Canada. He corresponded with assistants and colleagues around the country asking for information and plans on relevant works elsewhere, before finalising his designs.

\section{Letting the contracts}

On 22 November 1825 the draft contracts were approved and a fast construction programme drawn up. It was agreed that work on the entrance basin should begin as soon as possible, with a view to its being ready on 1 August 1827; the west dock should begin on 24 June 1826 and be ready by 27 September 1827; and work on the east dock was to begin on 25 June 1827 and be ready by 25 June 1828 .

The tenders were opened on 10 January 1826, as follows

\footnotetext{
Hugh McIntosh, $£ 326100$

- George Burge, £225000

- Thomas Townsend, £392515

- Thomas Thatcher, £345 495.
}

McIntosh $^{7}$, Townsend ${ }^{7}$ and Thatcher ${ }^{7}$ were well-known names. It was, however the tender of Burge, now best known as the developer of Herne Bay and contractor for Box Tunnel on the GWR, that was closest to Telford's estimate. It was decided to request more information of Burge on his experience and sureties. His tender for all the work was accepted on 17 January 1826 , and it proved an inspired choice. On 24 January 1826 he was asked to provide $£ 25000$ in sureties and was to start work on 25 March.

\section{Construction}

Work now began on what Telford described thus.

'As a practical engineer, responsible for the success of difficult operations, I must be allowed to protest against such haste, pregnant as it was, and ever will be, with risk which in more instances than one severely tasked all my experience and skill, involving dangerously the reputation of the directors and their engineer ${ }^{29}$

The directors were evidently keen to complete the docks as quickly as possible, encouraged by the prospect of profits and a return on the authorised capital of nearly $£ 2$ million. Delays in clearing the site meant work could not begin until the end of May 1826, by which time
Thomas Rhodes, who had assisted Telford on the Menai Bridge, was appointed as assistant to Logan. ${ }^{7,34}$ Progress remained slow for the first six months as Burge found it difficult to access the site.

By the end of October, however, he had 12 piling engines working on the cofferdams. Gravel was dredged to expose the London Clay. From low water level to the river bed four rows of piles were driven and infilled with clay. The three outer rows of piles continued above highwater level, and the inner dam was finished with bricks laid in sand to prevent shrinkage of the clay. The whole was tied together with 2 in $(50 \mathrm{~mm})$ diameter iron bolts, and braced with raking piles. As the lock wall behind was built up, the dam was braced off this.

The formal opening of the western dock took place on 25 October 1828. This was made

Table 2. Plans, specifications and revised estimates of Telford and Logan, 11 October 1825

\begin{tabular}{|lr|}
\hline Estimate for works & $£ 230365$ \\
Excavation and cofferdam & $£ 54097$ \\
Entrance basin & $£ 48 \quad 126$ \\
East dock & $£ 59656$ \\
West dock & $£ 68465$ \\
Approaches, etc. & $£ 11518$ \\
\hline Total estimate for works and approaches & $£ 24 \mid 883$ \\
\hline Parliamentary estimate & $£ 303237$ \\
\hline
\end{tabular}

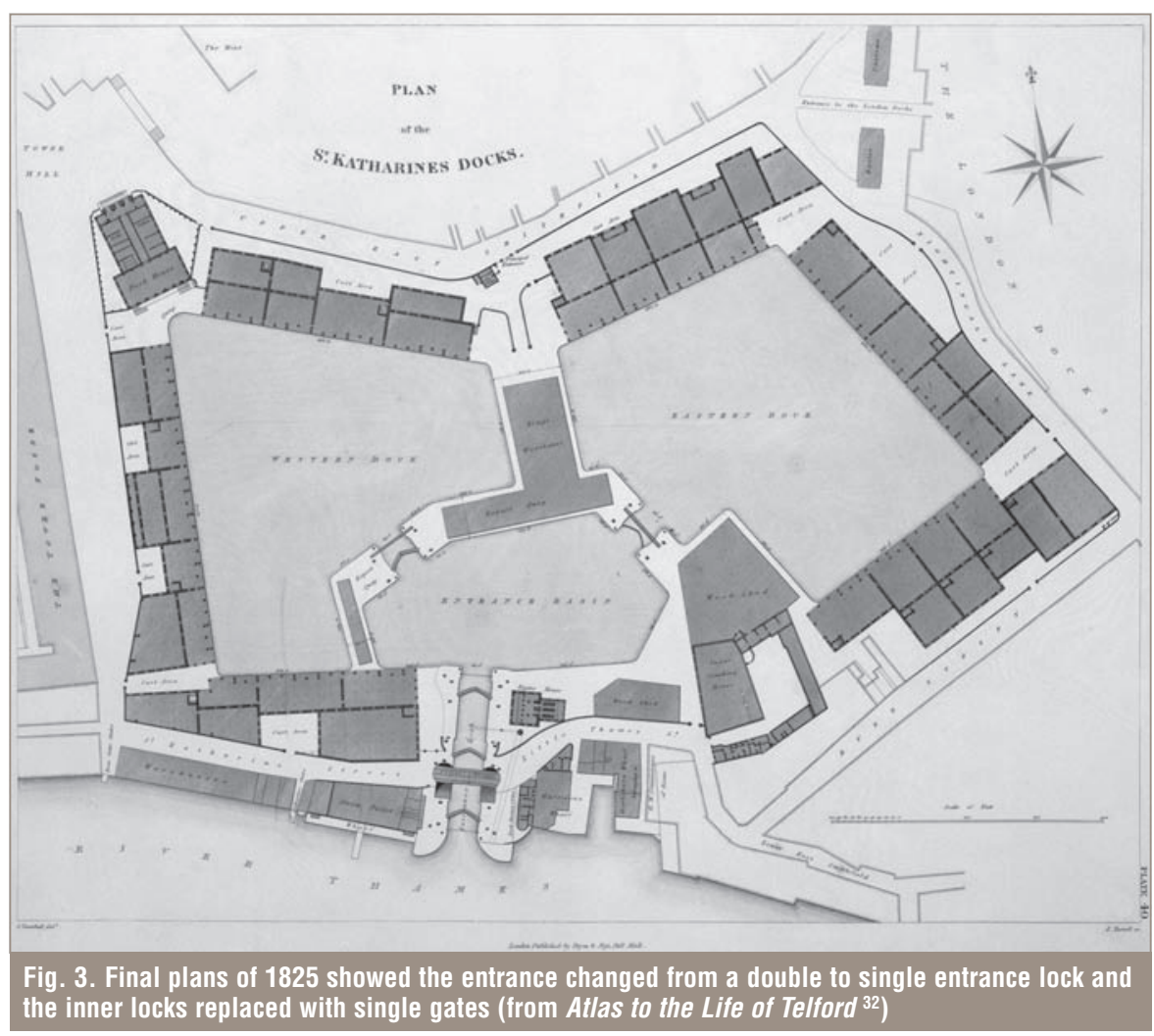




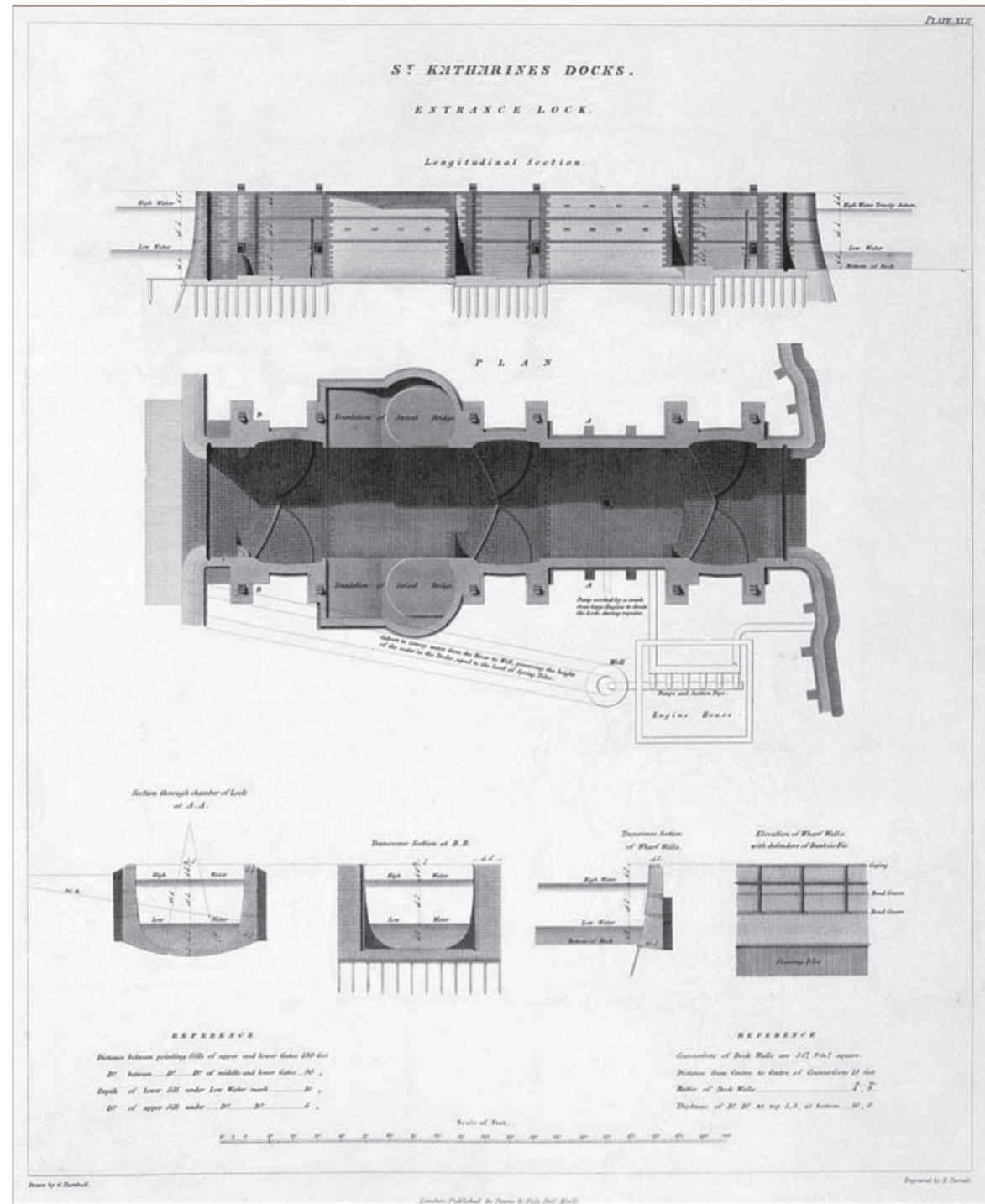

Fig. 4. Drawings for the $55 \mathrm{~m}$ long entrance lock, which could be filled in less than 6 minutes (Atlas to the Life of Telford ${ }^{32}$ )

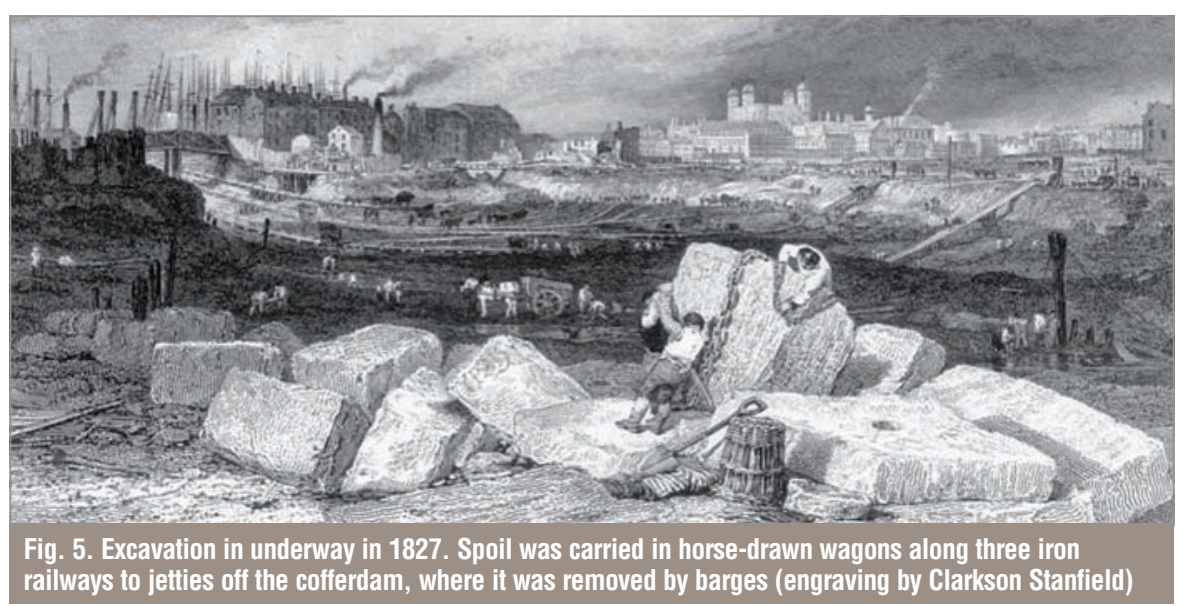

possible by Telford's skilful design, which enabled the two docks, via the basin, to operate independently. He had also worked hard on the design of the locking arrangements to allow the entry of ships even at fairly low tide levels with a deep tow sill, and to keep the basin filled up to dock level. Telford had dispensed with the inner locks and introduced a single pair of gates in each passage.

James Watt (junior) had designed the pumping arrangements with James Brown. The entrance lock was filled partly by pumping with two $8 \mathrm{hp}(6 \mathrm{~kW})$ engines from the river and partly via sluices from the basin. The basin could be refilled while vessels passed through the lock. The lock could be filled in $5^{1 / 2}$ min-a remarkable achievement.

The entrance lock itself was $180 \mathrm{ft}(55 \mathrm{~m})$ long, with a middle pair of gates which could be used with smaller vessels (Fig. 4). The sills of the outer and middle gates were $28 \mathrm{ft}$ $(8.5 \mathrm{~m})$ below Trinity high water, the ordinary spring tide data used in the port, ensuring ships had a clearance of at least $20 \mathrm{ft}(6 \mathrm{~m})$ from $2 \mathrm{~h}$ before to half an hour after neap tides, and longer at spring tides. The working arrangements permitted access to the basin at all times. An elegantly detailed cast-iron swing bridge was provided for the entrance by Seward in a contract of June 1827.

The first stone was laid on 3 May 1827. By late 1827 an engraving by Stanfield (Fig. 5) shows the scale of operations in the basins, with three iron railways being made to remove spoil in horse-drawn wagons to jetties off the cofferdam where it was removed by barges. In May contracts had been signed with Joseph Bramah ${ }^{7}$ for the lock and dock gates and with Bennett and Hunt for Hardwick's warehouses. Bramah's drawings are now to be seen in the Science Museum archives: a copy of the catalogue is in the ICE archives

The dock walls were $33 \mathrm{ft}(10 \mathrm{~m})$ high and $10 \mathrm{ft}(3 \mathrm{~m})$ thick at the base, with a curved batter-typical of early dock walls-founded on lime concrete $1 \mathrm{ft}(0.3 \mathrm{~m})$ thick, with a row of timber sheet piles $14 \mathrm{ft}(4.3 \mathrm{~m})$ deep beneath the front face of the walls (Fig. 6). ${ }^{35-37}$ The dock bottom was lined with puddle clay. Telford took particular care to prevent water ingress to the vaults of the warehouse by selection of mortar.

\section{Floods and subsidence}

Burge was employing around 1000 men, but the dangers of which Telford spoke were apparent on the night of 31 October 1827. An exceptionally high tide breached the bank at St Katharine's Thames Street and the workings were flooded in $15 \mathrm{~min}$, fortunately without loss of life. It took a fortnight to pump out the excavations. Despite all efforts, the programme was now well behind schedule. 
In January 1828 the rapid rate of progress is apparent from a drawing by Phelps, with one warehouse near complete (Fig. 7). John Hall replaced Logan as resident engineer at this time. With the opening of the western dock in October 1828, work could now be concentrated on the eastern dock. Unfortunately, Hall died in November 1828 . The company was fortunate that in Thomas Rhodes they had an immediate successor with knowledge of the works, which he saw through to completion on 27 October 1829. A small retracting footbridge bridge that he designed over the entrance to the eastern dock was supplied by Lloyds.

Work then proceeded on a steam packet wharf $170 \mathrm{ft}(52 \mathrm{~m})$ long on the Thames. Here again issues of which Telford had warned were evident. In this case the contractor selected on the basis of the lowest tender was Thomas Carpe. He began work in February 1829 on

An exceptionally high tide breached the bank at St Katharine's Thames Street and the workings were flooded in $15 \mathrm{~min}$, fortunately without loss of life

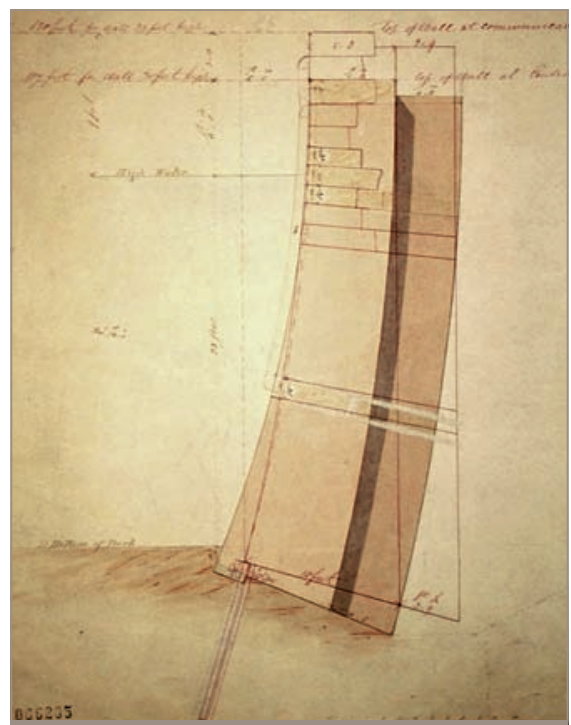

Fig. 6. Stone masonry dock walls $10 \mathrm{~m}$ high and $3 \mathrm{~m}$ thick at the base were founded on $0.3 \mathrm{~m}$ lime concrete, with a row of $4.3 \mathrm{~m}$ deep timber sheet piles beneath the front face (Telford bequest, Museum of London, Docklands) the wharf, which was located to the west of the entrance lock. Disregarding the contract specification and Rhodes' instructions, he extracted gravel to a dangerous level below the foundations of the wharf. The inevitable occurred, and the wall subsided. Carpe was dismissed and Burge repaired the wall for $£ 1000$.

\section{Opening}

By May 1830 work was virtually complete on the docks (Fig. 8). Telford was retained until the end of June and Rhodes until the end of the year. The warehouses around the dock were by then complete and Hardwick left in December 1830. Total expenditure was of the order of $£ 2$ million and the dock work had cost around $£ 250$ 000. Burge was paid a bonus of $£ 17834$ to ensure the early opening of the dock.

In December 1828, with the docks partly open, John Capel MP declared to his fellow shareholders

'In the beginning of May 1827 the first stone was laid and in the space of sixteen months the work had reached its present form, where there had previously been a chaos of filth, vice and wretchedness splendid buildings had been erected, and the transactions of commerce were carried on with vigour and industry.'

The docks today

St Katharine's location close to the City of London means the docks remain as attractive a location for development in the early twentyfirst century as they were 200 years ago. ${ }^{38}$ The docks were severely damaged by bombing in the Second World War, and the Port of London

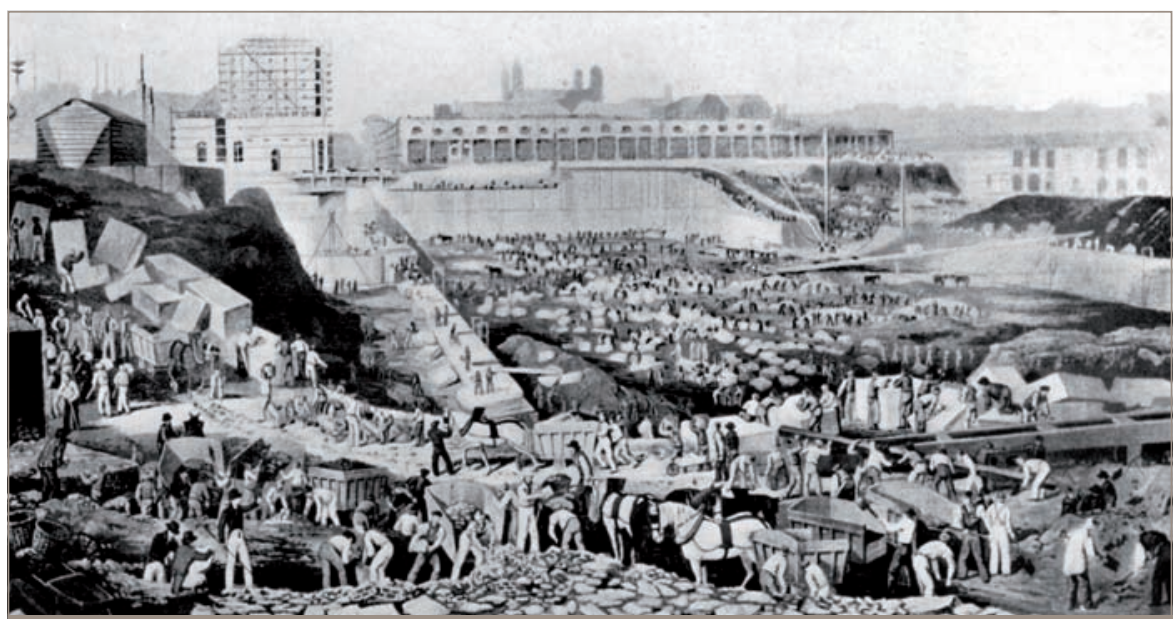

Fig. 7. Work in full swing in January 1828, with around 1000 men on site. By this time one of the warehouses has been substantially completed (aquatint by J. Phelps after painting by W. Ranwell, Port of London Authority (PLA) collection).

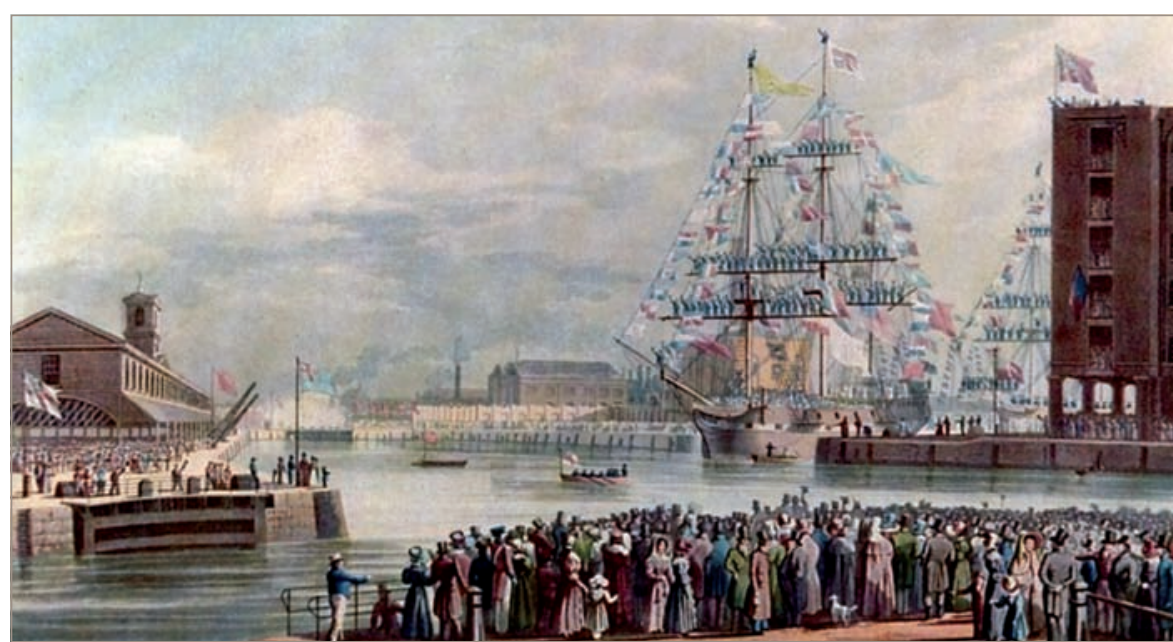

Fig. 8. The western dock opened on 25 October 1828: a year behind schedule, but still only took two and half years to build (engraving after painting by Huggins, PLA collection) 
Authority never fully repaired or redeveloped the site. The quays around the eastern dock and the north-west corner went out of use and Hardwick's array of six large warehouses was severely depleted, with the three enclosing the eastern dock being totally destroyed and two around the western dock being partially gutted. Despite this, the docks were in use throughout the 1950s and most of the 1960s (Fig. 9). ${ }^{20}$

The entrance lock was rebuilt in 1957 (Fig. 10). Water had been seeping beneath the entrance gate platforms when the gates were closed. In that year it was decided to close the lock and rebuild the platforms, installing bottomed-hinged flap gates. When the lock entrance was drained down between cofferdams, Telford's original construction was exposed: a framework of heavy timbers supported on piles in London clay, with a gravel mat between the timbers on which Bramley Fall stone was laid to form the gate platform. Bomb damage had enabled water to get under the timbers and the hydrostatic pressure had lifted the stones-some were displaced by more than $6 \mathrm{~m}$ from the entrance. As a result, it was necessary to demolish and rebuild the whole of the outer dock wall and sill, and provide new steel sheet pile cut-offs there and for the inner gates. ${ }^{39}$

The docks had over 1.25 million $\mathrm{ft}^{2}$ $\left(116000 \mathrm{~m}^{2}\right)$ of storage and held a wide range of goods. By 1965, however, they were operating at a loss, and the cramped site and confined water space meant they would never be redeveloped for container traffic, which was transforming maritime cargo handling. The docks were closed to shipping in 1968 and the warehouses were shut in 1969. London Docks next door closed in May 1969.

St Katharine Docks then became the focus for redevelopment, and one of the first instances of civil engineering infrastructure being used as the core for urban regeneration. In 1969 the Greater London Council (GLC) acquired the site for $£ 1.8$ million—a similar figure to the original cost of the scheme, and a knock-down price allowing for inflation. ${ }^{40}$ Schemes were invited from developers.

Taylor Woodrow won the competition, being the only one proposing substantial reuse of the historic structures. The company took a long lease and a mixed development of private and social housing, hotel, offices, restaurants and marina facilities resulted (Fig. 11). Ove Arup \& Partners was civil and structural engineer for much of the scheme. Popular with visitors, its success pointed the way for dockland developments elsewhere in London, and subsequently in Liverpool, Hull and elsewhere.

Fortunately, Telford's dock structures remain, with the greatest changes being above the quay-

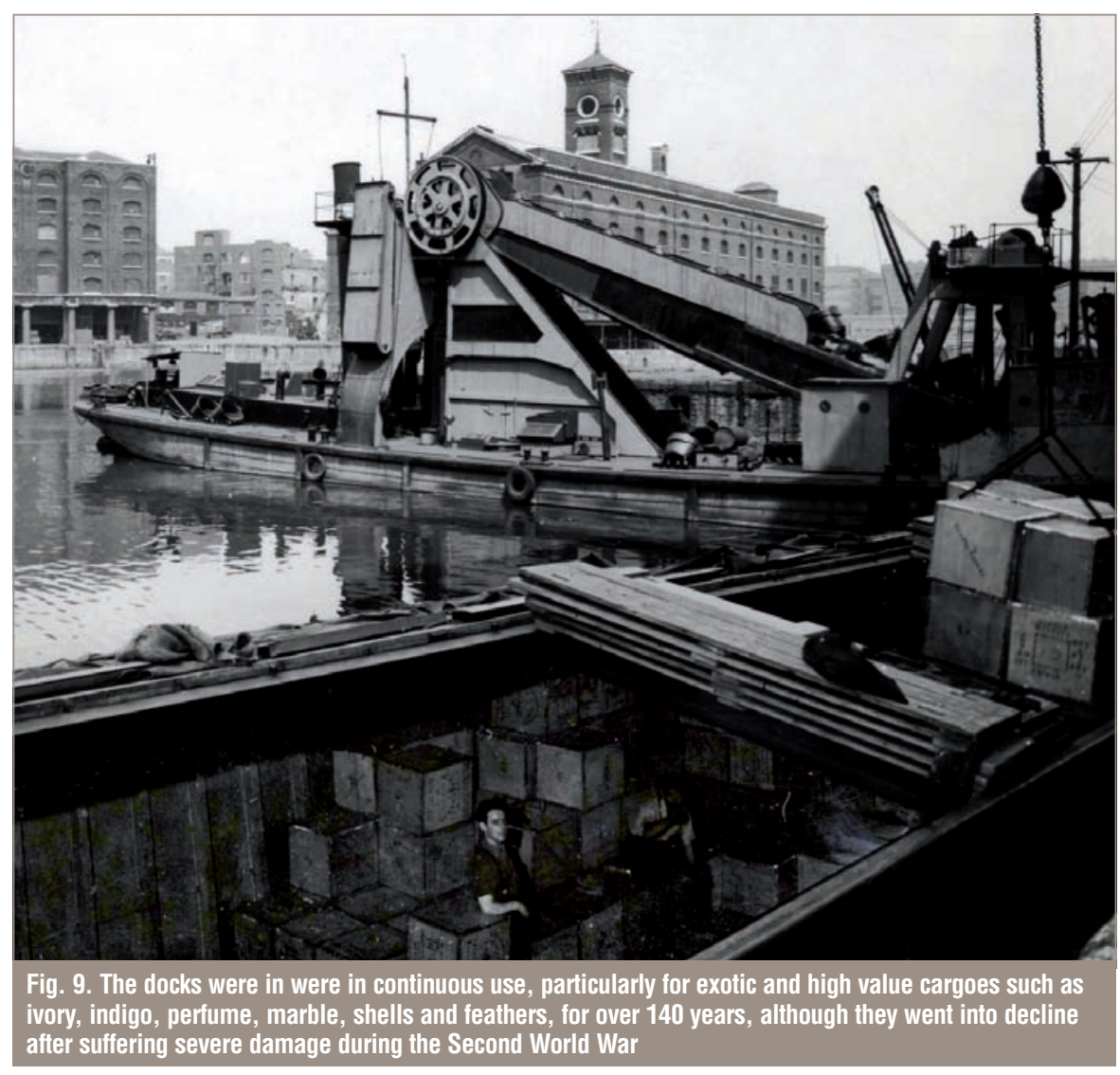

side where little of the nineteenth century construction remains. In that respect, the demolition of the three original warehouse blocks remaining around the western dock- 'A' in 1970, 'B' in 1977-78 and ' $C$ ' in 1980 — would not have been tolerated a decade later. So anxious was the GLC to see the site redeveloped that it failed to insist upon reuse in the recession that came in the 1970s. Although a proposal to retain and adapt 'B' warehouse alongside Tower Bridge Approach was made, it was frustrated by a disastrous fire in 1973.

The later 1850s 'I' warehouse, which stands on the peninsula between the two docks with a T-shaped plan, has been converted to luxury apartments, retail units and offices and is now known as Ivory House. Part of ' $G$ ' warehouse, a timber-framed structure pre-dating the construction of the docks, was braced and moved bodily to its present location and now serves as the Dickens Inn public house. ${ }^{41,42}$

Hardwick must be considered an unlucky architect, as his spectacular work at Euston station including the great Doric arch suffered a similar fate in the 1960s. The small retractable footbridge over the entrance to the eastern dock, designed by Thomas Rhodes, is now a static quayside feature, while the original locking arrangements and other moveable bridges have been replaced long ago.

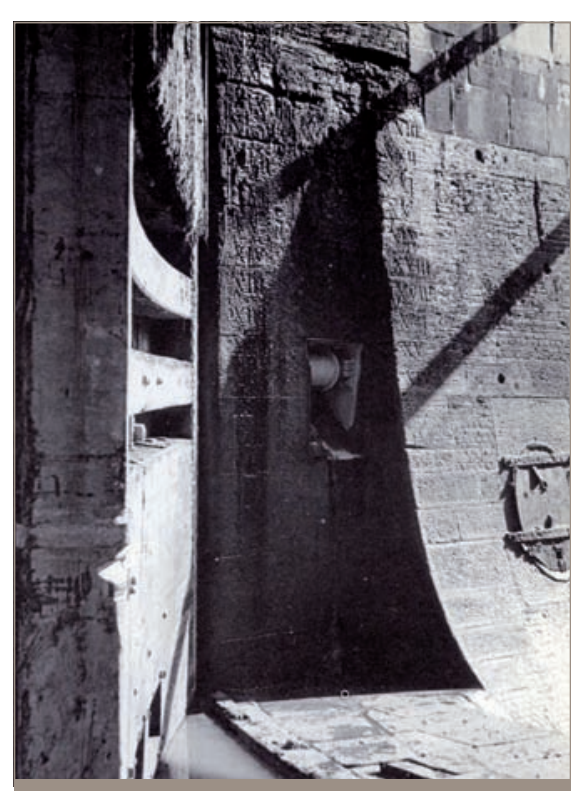

Fig. 10. Entrance lock drained down for reconstruction in 1957. Bomb damage had allowed water to flow under the lock gate platiorms (Museum of London in Docklands collection) 
The docks were recently sold by Taylor Woodrow to St Katharine's Investments, a partnership of REIT Asset Management and Apollo investments, which since 2005 have been developing plans for a further $£ 100$ million rejuvenation scheme. At the time of the sale of the St Katharine's Estate by Taylor Woodrow for $£ 163$ million, rented income was declared as £10.9 million in 2003 and $\$ 8.9$ million in $2002.43,44$

\section{Conclusions}

The Telford docks, as built with their distinctive enclosed warehouses and ingenious locking arrangements, are of great interest today. Even in 1830, however, operational weaknesses were evident. The locks were not capable of handling large vessels, unlike those in the other London docks built 30 years earlier. These docks provided excess capac- ity and undermined the financial position of competition.

In 1864 they were merged with the London Docks group. Nevertheless the docks functioned for 140 years, indeed until the entire up-river London docks system was undergoing complete closure.

Today, although Hardwick's original warehouses have gone, Telford's high-quality dock works can still be appreciated (Fig. 12).
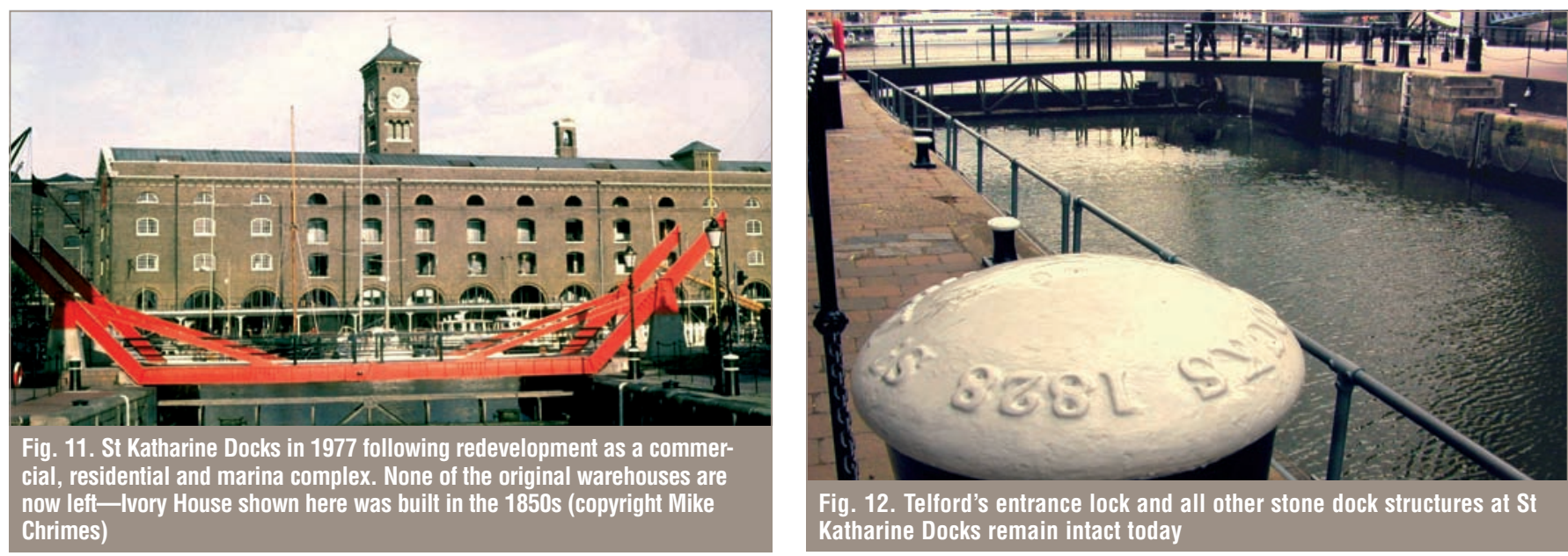

Fig. 12. Telford's entrance lock and all other stone dock structures at St Katharine Docks remain intact today

References

I. GIBB A. The Story of Telford. Maclehose, London, 1935.

2. ROLT L. T. C. Thomas Telford. Penguin, London, 2007 (reprint).

3. BURTON A. Thomas Telford. Aurum, London, 1999

4. COMMITTEE ON THE SURVEY OF THE COASTS OF SCOTLAND. Third report, I80I.

5. TELFORD T. A copy of a letter to the Secretary of the British Societies...Parker's cement. 1796.

6. TELFORD T. A survey... of the coasts and central Highlands of Scotland. 1802. London, 1803.

7. Chrimes M., SKempton A., RenNison R. W, COX R. C., RUDDOCK T. and CROSS-RUDKIN P. (eds). Biographical dictionary of Civil Engineers of Great Britain and Ireland 1500-1830 (BDCEI). Thomas Britain and Ireland 1500

8. HAdField C. and SKempton A. W. William Jessop, Engineer. David \& Charles, Newton Abbot, 1979.

9. BOUCHER C. T. G. John Rennie 1761-I82I. University Press, Manchester, 1963.

10. SKEMPTON A. W. Landmarks in early soil mechanics. European Conference on Soil Mechanics and Found Engineering 7, Brighton, 198I, 5, I-26

II. SMEATON J. The Reports by Smeaton, Rennie and Telford upon the Harbour of Aberdeen. Aberdeen, 1834.

12. TELFORD T. Report respecting the Harbour of Dundee, 1814 and Report relative to the plans of the New Ferry Harbours at Dundee, I821.

13. SOUTHEY R. Journal of a Tour in Scotland in 1819. Murray, London, 1929.

14. SMILES S. Lives of the Engineers. London, I86I, Vol. 2 , p. 391.

15. TELFORD T. et al. Reports on the improvement and management of the River Clyde, Glasgow, 1854.
16. SKempton A. W. Engineering in the Port of London Transactions of the Newcomen Society, 1978-79, 50, 87-108.

17. SKEMPTON A. W. Engineering in the Port of London Transactions of the Newcomen Society, $|98|-82,53$. 73-96.

18. ELMES J. A scientific, historical and commercial survey of the Port of London. In Public works of Great Britain (Simms W. ed.)). Weale, London, 1838.

19. PUDNEY J. London's Docks. Thames and Hudson, London, 1975.

20. GREAVES I. London Docks, 1800-1908. Thomas Telford, London, 1980.

21. RITCHIE-NOAKES N. Liverpool's Historic Waterfront. Her Majesty's Stationery Office, London, 1984.

22. BALDWIN M. W. The engineering history of Hull's earliest docks. Transactions of the Newcomen Society, 1973-74, 46, I-12.

23. CHRIMES M. M. British civil engineering biography, Civil Engineering, Proceedings of the Institution of Civil Civil Engineering, Proceedings of the Instituti
Engineers. 2004, 157, 91-96, 140-144.

24. PARLIAMENT. Select Committee on Maintaining and Improving the Foreign Trade... 1823-24.

25. INSTITUTION OF CIVIL ENGINEERS. Plans of S Katharine's Docks. Gibb Collection. ICE, London.

26. SMITH D. James Walker (I78I-1862). Transactions of the Newcomen Society, 1997, 69, No. I, 23-55

27. Colvin H. M. A Biographical Dictionary of British Architects 1600-1840, 3rd edn. Yale, London, 1995.

28. MUSEUM OF LONDON IN DOCKLANDS. Prospectus, 28 February 1824.

29. RICKMAN J. (ed). The Life of Thomas Telford. London, I838, p.I52.

30. MITCHELL J. Reminiscences of my life in the Highlands, 1883-84. Reprinted by David \& Charles, Newton Abbot, 1971.
31. CROSS-RUDKIN P. S. M. (ed.) Biographical Dictionary of Civil Engineers, 1830-1890. Thomas Telford, London, 2007.

32. TelFORD T. Atlas to the life of Telford. Payne \& Foss, London, 1838.

33. TELFORD T. Edinburgh Encyclopaedia. Brewster, Edinburgh, 1812 .

34. Civil Engineer and Architects Journal, 1839, 2, 430-433.

35. BRAY R. N. and TATHAM P. F. B. (eds) Old waterfront walls: management, maintenance and rehabilitation. walls: management, $m$.

36. CUR CENTRE FOR CIVIL ENGINEERING. Handbook Quay Walls. Taylor and Francis, London, 2005.

37. INSTITUTION OF CIVIL ENGINEERS. Minutes of Conversations, I830, 7I, 26 January.

38. TUCKER M. Industrial developments from 1800 to the C20. Introduction to Buildings of England. London: Docklands (WILLIAMSON E. and PEVSNER N. (eds)), Penguin, London, 1998, pp. 28-4I.

39. North East London Polytechnic. Dockland. London, GLC, 1986.

40. TUCKER M. St. Katharine Docks. Arup Journal, 1970, 5 No. 3, 10-19.

4I. PITTS J. C., EAley T. A. and LidDell W. I. G Warehouse: the resisting and renovation of an antique timber framed building at St. Katharine's dock. The Structural Engineer, 1975, 53, No. 10 , 415-429.

42. PitTs J. C., Ealey T. A. and Liddell W. I. Discussion. The Structural Engineer, 1977, 55, No. 3, pp. 133-138.

43. TAYLOR WOODROW. Press release, 27 February 2004. Available online at: http://www.taylorwoodrow.com (accessed 6 January 2007).

44. ST KATHARINE'S DOCKS. Available online at: http:// www.skdocks.co.uk (accessed 6 January 2007).

What do you think? If you would like to comment on this paper, please email up to 200 words to the editor at editor@ice.org.uk. 